\title{
ORGANISMOS MODIFICADOS GENÉTICAMENTE. PROTOCOLO SOBRE SEGURIDAD DE LA BIOTECNOLO- GÍA
}

\author{
María Angustias JimÉnez Lucena ${ }^{1}$
}

\begin{abstract}
RESUMEN
Las técnicas modernas de manipulación genética permiten actuar sobre la información contenida en el material hereditario añadiendo o eliminando genes de manera que el hombre puede obtener organismos modificados genéticamente (OMG).

La aplicación de estas técnicas a la agricultura produce grandes cambios para los agricultores porque los introduce en una dimensión productiva bastante diferente a la tradicional, supone grandes posibilidades de desarrollo económico y mejora en la calidad de vida de la humanidad, pero a la vez conlleva la responsabilidad de asegurar que dicha aplicación se realice en condiciones en las que los posibles riesgos para la salud humana o el medio ambiente sean mínimos, lo que exige la adopción de una serie de medidas de garantía y control de las actividades en las que se produzcan o empleen organismos modificados genéticamente.

El avance de la biotecnología moderna en los últimos años ha motivado el interés de diferentes organizaciones internacionales sobre la bioseguridad y la necesidad de establecer normas comunes que permitan la comercialización de productos biotecnologicos en igualdad de condiciones para los diferentes países.

El presente trabajo analiza las posturas y argumentos planteados por los Estados en la negociación del Protocolo sobre Seguridad de la Biotecnología realizado en el marco de Convenio sobre la Diversidad Biológica, mostrando la complejidad y la fuerte polemica generada por los Organismos Modificados Genéticamente.
\end{abstract}

Palabras claves: transgénico, biotecnología, bioseguridad.

\section{SUMMARY}

\section{Organisms Modified Genetically. The Protocol of Security of the Biotechnology}

The modern techniques of genetic manipulation allow to act about the information contained in the hereditary material adding or eliminating genes so that the man can obtain organisms modified genetically (OMG).

The application of these techniques to the agriculture produces big changes for the farmers because it introduces them in a productive dimension quite different to the traditional one, it supposes big possibilities of economic development and it improves in the quality of the humanity's life, but at the same time it bears the responsibility of assuring that this application is carried out under

1.- Cátedra de Legislación y Política Agraria. Facultad de Ciencias Agrarias,Universidad Nacional del Litoral. Kreder 2805, ( 3080) Esperanza, provincia de Santa Fe. Telefax (03496) 426400.

Manuscrito recibido el 27 de diciembre de 2000 y aceptado para su publicación el 12 de noviembre de 2001. 
conditions in those that the possible risks for the human health or the environment are minimum, what demands the adoption of a series of guarantee measures and control of the activities in those that take place or use organisms modified genetically.

The advance of the modern biotechnology in the last years has motivated the interest of different international organizations about the biosafety and the necessity of common norms that allow the commercialization of biotechnical products in equality of conditions for the different countries settling down.

The present work analyzes the postures and arguments outlined by the States in the negotiation of the Protocol on Biosafety carried out in the mark of Convention on Biological Diversity, showing the complexity and the strong polemic generated by the Organisms Modified Genetically.

Key words: transgenic, biotechnology, biosafety. 